\title{
Carbon storage and net primary productivity in Canadian boreal mixedwood stands
}

\author{
Nicholas J. Payne ${ }^{1}$ D. Allan Cameron ${ }^{1} \cdot$ Jean-Denis Leblanc $^{1} \cdot$ Ian K. Morrison $^{1}$
}

Received: 15 May 2018/ Accepted: 23 August 2018/Published online: 27 February 2019

(C) The Author(s) 2019

\begin{abstract}
Canadian boreal mixedwood forests are extensive, with large potential for carbon sequestration and storage; thus, knowledge of their carbon stocks at different stand ages is needed to adapt forest management practices to help meet climate-change mitigation goals. Carbon stocks were quantified at three Ontario boreal mixedwood sites. A harvested stand, a juvenile stand replanted with spruce seedlings and a mature stand had total carbon stocks $( \pm \mathrm{SE})$ of $133 \pm 13$ at age $2,130 \pm 13$ at age 25 , and $207 \pm 15 \mathrm{Mg} \mathrm{C}^{-1}$ at age 81 years. At the clear-cut site, stocks were reduced by about $40 \%$ or $90 \mathrm{Mg} \mathrm{C}^{-1}$ at harvest. Vegetation held 27, 34 and $62 \%$ of stocks, while detritus held 34, 29 and $13 \%$ of stocks at age 2, 25 and 81, respectively. Mineral soil carbon stocks averaged $51 \mathrm{Mg} \mathrm{C} \mathrm{ha}^{-1}$, and held 38, 37 and $25 \%$ of stocks. Aboveground net primary productivity $( \pm \mathrm{SE})$ in the harvested and juvenile stand was $2.1 \pm 0.2$ and $3.7 \pm 0.3 \mathrm{MgC} \mathrm{ha}^{-1}$ per annum (p.a.), compared to $2.6 \pm 2.5 \mathrm{Mg} \mathrm{C}^{-1}$ p.a. in the mature stand. The mature canopies studied had typical boreal mixedwood composition and mean carbon densities of $208 \mathrm{Mg} \mathrm{C}^{-1}$, which
\end{abstract}

Project funding: Funding for this study was provided by the Canadian Forest Service, with in-kind support from the Ontario Ministry of Natural Resources and Forestry.

The online version is available at http://www.springerlink.com

Corresponding editor: Chai Ruihai.

Nicholas J. Payne

nick.payne@canada.ca

1 Canadian Forest Service, Great Lakes Forestry Centre, 1219 Queen St. East, Sault Ste. Marie, ON P6A 2E5, Canada is above average for managed Canadian boreal forest ecosystems. A comparison of published results from Canadian boreal forest ecosystems showed that carbon stocks in mixedwood stands are typically higher than coniferous stands at all ages, which was also true for stocks in vegetation and detritus. Also, aboveground net primary productivity was typically found to be higher in mixedwood than in coniferous boreal forest stands over a range of ages. Measurements from this study, together with those published from the other boreal forest stands demonstrate the potential for enhanced carbon sequestration through modified forest management practices to take advantage of Canadian boreal mixedwood stand characteristics.

Keywords Aboveground net primary productivity - Boreal mixedwood forest - Carbon stocks - Mixedwood stand management $\cdot$ Stand age

\section{Introduction}

Climate change, caused by increasing atmospheric $\mathrm{CO}_{2}$ concentration resulting from fossil fuel use, is a pressing concern of international scope (IPCC 2014). Managing terrestrial carbon sinks to ameliorate the problem of increasing $\mathrm{CO}_{2}$ concentration is of prime interest (IPCC 2014). The world's forests have been estimated to contain about $80 \%$ of all aboveground carbon and $40 \%$ of all belowground carbon (Dixon et al. 1994), and forests are recognized as important global carbon (C) sinks and sources (Landsberg and Gower 1997) that play a key role in the atmospheric carbon dynamics and climate change mitigation.

Around the globe, boreal forests cover 1220 million ha and are the world's second largest forest biome (Landsberg 
and Gower 1997). It is therefore important to consider their management in relation to the goal of increasing carbon stocks and sequestration in forests. Forested land covers 348 million ha in Canada (Natural Resources Canada 2012), including 223 million ha of boreal forest (Brandt 2009), and of this total, mixedwood forest occupies some 152 million ha (Baldwin et al. 2012). Canada's managed boreal forest occupies 54\% of the nation's total boreal forested area, with $28 \mathrm{Pg}$ of carbon in biomass, organic matter and soil pools (Kurz et al. 2013). Boreal mixedwood stands in the province of Ontario, which are defined as those in which no single species exceeds $80 \%$ of basal area (MacDonald 1995), occupy 15.3 million ha or $53 \%$ of the forested land base (Towill 1996).

The commonest tree species in mature Canadian boreal mixedwood stands are trembling aspen (Populus tremuloides Michx.), white birch (Betula papyrifera Marsh.), black spruce [Picea mariana (Mill.) B.S.P.], white spruce [Picea glauca (Moench) Voss], and balsam fir [Abies balsamea (L.) Mill.]; these stands are disturbance-related and represent a mid-successional stage in forest development. Early stages are generally aspen-dominated and late stages are spruce-fir-birch dominated. The two natural disturbances that most commonly occur in boreal mixedwood stands are wildfire and spruce budworm (Choristoneura fumiferana Clem.) infestations, while manmade disturbances include harvesting and planting, which in some cases may lead to species conversion.

Boreal mixedwoods are complex forests in which different species accumulate biomass at different rates and utilize different resources at a site (Paré and Bergeron 1995) and have been considered the most productive forest ecosystems in North American boreal forest (Chen and Popadiouk 2002), although more recent research suggests that aspen-dominated stands may be more productive (Laganière et al. 2015). The diversity of species supported on a boreal mixedwood site suggests efficient use of the land available for tree growth, with each species exploiting its niche within the ecosystem such that total production on the site reflects the best growth that each tree species can offer (Légaré et al. 2004). Boreal mixedwoods often occupy the more fertile sites, and, because of their extensive areal coverage, play an important role in carbon sequestration in Canadian forests. Regionally, Liu et al. (2002) noted that Ontario's boreal forests were relatively young, with an average age of 36.2 year in 1990, a further indication of their potential for $\mathrm{C}$ sequestration and storage. Knowledge of the total ecosystem carbon stocks in the extensive Canadian boreal mixedwood biome is therefore needed to design forest management strategies to enhance sequestration and storage at different stages of development and contribute to climate change mitigation. The need for further quantification of the climate change mitigation potential of Canada's boreal zone and the benefits of implementing forestry management practices has been noted by Lemprière et al. (2013). Quantification of the carbon stocks and net primary productivity at different stages of boreal mixedwood stand development are also of value for carbon budget model development and validation (e.g., Li et al. 2002). Modelling Canada's forest carbon content and projecting its' overall effectiveness in sequestering carbon from the atmosphere is foundational for policy discussions around possible climate change mitigation measures.

In this study, we quantified ecosystem carbon stocks and aboveground net primary productivity in typical Ontario boreal mixedwood stands at different stages of development, including a mature stand ( $>65$ year) before and after harvesting, a juvenile stand replanted with softwood seedlings, and an intact mature stand. Specifically, our goals were to assess the effect of clear-cut harvesting on ecosystem carbon stocks and aboveground net primary productivity, to quantify ecosystem carbon stocks and aboveground net primary productivity in a juvenile stand replanted with softwood seedlings and in mature Ontario boreal mixedwood forest, and to assess stocks in detritus and mineral soil in a replanted juvenile stand and a mature mixedwood stand.

\section{Materials and methods}

\section{Study sites}

Study site details are provided in Table 1 . The sites were located within about $40 \mathrm{~km}$ of each other, near Timmins in northeastern Ontario. The mature stand at the McKeown Lake site $\left(48.166^{\circ} \mathrm{N}, 81.550^{\circ} \mathrm{W}\right)$ was sampled at age 69 years in 2006, and was then clear-cut harvested in late 2008 and early 2009, and re-assessed at age 2 in 2011. The juvenile stand, which was planted with spruce seedlings after clear-cut harvesting to achieve stand conversion (Childerhose Township site $48.133^{\circ} \mathrm{N}, 81.628^{\circ} \mathrm{W}$ ), was quantified at ages 20 (2006) and 25 years (2011). Harvested boreal mixedwood stands are sometimes planted with coniferous seedlings to add commercially desirable species and enhance stand productivity. These two sites were approximately $2 \mathrm{~km}$ away from each other and shared many climatic and soil descriptive features. Both are ground moraines of silty to sandy tills and predominantly humo-ferric podzol (Bélisle 1980; Soil Classification Working Group 1998). Soil moisture is fresh, the topography is simple, and site elevation lies between $365 \mathrm{~m}$ and $380 \mathrm{~m}$ a.s.l. (Chapman and Thomas 1968). The other mature stand, at the Groundhog River site $\left(48.217^{\circ} \mathrm{N}\right.$, $\left.82.156^{\circ} \mathrm{W}\right)$, was measured at stand age 74 (2003) and 
Table 1 Study design

\begin{tabular}{llll}
\hline Site & Measurement ages (year) & Management practice & Sampling plot count \\
\hline Childerhose Township & 20,25 & Replanted with softwood & 8 \\
Groundhog River & 74,81 & Intact mature stand & 9 \\
McKeown Lake & 69,2 & Mature stand, cleacut harvest & 8 \\
\hline
\end{tabular}

81 years (2010). The soil at this site is a sandy loam and characterised as a dystric brunisol with pockets of orthic gleysol. Soil moisture is fresh to very fresh, the topography is simple and flat, and site elevation is $340 \mathrm{~m}$ a.s.l.

\section{Site climate}

The weather pattern at the sites is a modified continental climate. These sites typically experience 160 growing days, i.e., the number of days when the mean temperature is above $5.6{ }^{\circ} \mathrm{C}\left(42{ }^{\circ} \mathrm{F}\right)$. Growing days typically begin around May 3 and end around October 12 (Chapman and Thomas 1968). Normals for the period $1971-2000$ are $831 \mathrm{~mm}$ of annual precipitation, with $558 \mathrm{~mm}$ as rainfall and $3.1 \mathrm{~m}$ as snowfall (Environment Canada 2013). These data were collected at Timmins Airport, about $40 \mathrm{~km}$ from the Childerhose and McKeown Lake sites and $70 \mathrm{~km}$ from the Groundhog River site.

\section{Sampling methodology}

Sampling plots were established to assess vegetation, woody debris and soil properties using the Canadian National Forest Inventory plot establishment protocol (National Forest Inventory 2008). Twenty-five sampling plots were distributed over the three sites, with 8 plots installed on a $300 \mathrm{~m} \times 300 \mathrm{~m}$ grid at both the juvenile site and the harvested mature site, and 9 plots at the other mature site. Each sampling plot comprised a circular plot with $11.28 \mathrm{~m}$ radius (area $0.04 \mathrm{ha}$ ), in which all trees (i.e., diameter breast height $[\mathrm{dbh}] \geq 9 \mathrm{~cm}$ ) and stumps were measured, and a nested inner circular plot with $3.99 \mathrm{~m}$ radius (area $0.005 \mathrm{ha}$ ) that was used for measuring saplings $(\mathrm{dbh}<9 \mathrm{~cm})$. Within each sampling plot, four circular mini-plots with radius $0.56 \mathrm{~m}$ (area $0.0001 \mathrm{ha}$ ) were used for measuring shrubs and trees $<1.3 \mathrm{~m}$ in height, and destructive biomass sampling of shrubs, herbs and mosses. Woody debris was assessed along two 30-m transects intersecting at right angles at plot centre, following procedures described by Van Wagner (1968) and McRae et al. (1979). Size classes for fine, small and coarse woody debris refer to diameter ranges of $<1 \mathrm{~cm}, 1-7 \mathrm{~cm}$ and $>7 \mathrm{~cm}$, respectively. In addition, eight litterfall traps (sampling area $0.25 \mathrm{~m}^{2}$ ) were sampled annually at each sampling plot over a 5-year period. A soil pit was dug at the installation of each sampling plot to sample the forest floor and mineral soil layers to a depth of $60 \mathrm{~cm}$. The soil pit assessments were made at age 20 in the juvenile stand at the Childerhose site and at age 69 and 74 in the mature stands at McKeown Lake and Groundhog River sites. Stand characteristics at each site are provided in Tables 2 and 3. The mature sites were about $85 \%$ fully stocked, as determined by comparison of tree numbers, basal area and age for individual species.

Above- and belowground biomass were calculated using allometric equations of the form $M=a D^{b}$, where $M$ is dry mass of biomass component $(\mathrm{kg}), D$ is $\mathrm{dbh}(\mathrm{cm})$, and $a$ and $b$ are constants. This equation provided accurate biomass predictions with lower data requirements by precluding the need to measure plant height. Equations based on in-house measurements of trees and saplings, sampled in northern Ontario by Great Lakes Forestry Centre researchers, were available for most species. The equations used to calculate above- and belowground tree biomass for trembling aspen, white birch, white spruce, black spruce and balsam fir, with dbh ranges, are given in Table 4 . Where regional biomass equations were not available, those reported in the literature were employed (Ohmann et al. 1981; Crow and Erdmann 1983; Smith and Brand 1983; Perala and Alban 1994; Roussopoulos and Loomis 1979; Ter-Mikaelian and Korzukhin 1997; Brassard et al. 2011). Oven-dried samples of litterfall, forest floor organic layer, shrubs, herbs and mosses and soil samples were weighed and underwent chemical analysis to quantify carbon content at the Great Lakes Forestry Centre Soils Laboratory. Carbon content of trees, saplings and woody debris was taken as $50 \%$ of biomass (Amiro et al. 2001). Annual aboveground net primary productivity (AGNPP) was estimated from measurements made at each site. The repeated measurements of trees and sapling dbh were employed with allometric equations to estimate the annual aboveground biomass increment, and combined with measurements of understorey biomass and annual litterfall, to estimate total annual AGNPP. Statistical analysis of the data provided mean values with standard errors or deviations for each variable at the site of interest, for the stand age at quantification. 
Table 2 Mean $( \pm$ SE) stand density and basal area

\begin{tabular}{lccccccr}
\hline Stand age (year) & \multicolumn{2}{l}{ Stem density $\left(\mathrm{ha}^{-1}\right)$} & & \multicolumn{3}{l}{ Basal area $\left(\mathrm{m}^{2} \mathrm{ha}^{-1}\right)$} \\
\cline { 2 - 3 } & Live trees & Dead trees & Total & & Live trees & Dead trees & Total \\
\hline 2 & $19 \pm 10$ & $81 \pm 51$ & $100 \pm 52$ & & $0.3 \pm 0.2$ & $1.6 \pm 0.7$ & $1.9 \pm 0.7$ \\
20 & $241 \pm 54$ & $9 \pm 5$ & $250 \pm 54$ & & $2.4 \pm 0.5$ & $0.3 \pm 0.2$ & $2.7 \pm 0.5$ \\
25 & $897 \pm 152$ & $13 \pm 7$ & $910 \pm 152$ & $9.0 \pm 1.6$ & $0.2 \pm 0.1$ & $9.2 \pm 1.6$ \\
69 & $1094 \pm 137$ & $72 \pm 23$ & $1166 \pm 139$ & & $30.9 \pm 5.3$ & $2.4 \pm 0.9$ & $33.3 \pm 5.4$ \\
74 & $1072 \pm 116$ & $92 \pm 20$ & $1164 \pm 117$ & & $29.9 \pm 4.1$ & $2.1 \pm 0.6$ & $32.0 \pm 4.1$ \\
81 & $1039 \pm 111$ & $131 \pm 25$ & $1170 \pm 114$ & & $31.7 \pm 3.9$ & $3.5 \pm 0.9$ & $35.2 \pm 4.0$ \\
\hline
\end{tabular}

Table 3 Mean $( \pm \mathrm{SD})$ tree diameter $(\mathrm{dbh} \geq 9 \mathrm{~cm})$

\begin{tabular}{|c|c|c|c|c|c|c|c|c|}
\hline \multirow[t]{2}{*}{ Stand age (year) } & \multicolumn{8}{|l|}{$\mathrm{dbh}(\mathrm{cm})$} \\
\hline & Trembling aspen & White birch & White spruce & Black spruce & Balsam fir & Other species & Live trees & Dead trees \\
\hline 2 & $22.6 \pm 6.5$ & $18.1 \pm 3.3$ & - & - & $11.4 \pm 2.4$ & $10.7 \pm 0.1$ & $13.6 \pm 2.3$ & $20.6 \pm 3.5$ \\
\hline 20 & $10.1 \pm 0.3$ & $16.7 \pm 3.0$ & $11.0 \pm 0.8$ & $10.0 \pm 0.2$ & $11.1 \pm 0.4$ & $13.7 \pm 2.6$ & $10.9 \pm 0.3$ & $18.6 \pm 6.1$ \\
\hline 25 & $11.3 \pm 0.4$ & $12.5 \pm 1.0$ & $10.7 \pm 0.3$ & $10.9 \pm 0.1$ & $11.7 \pm 0.3$ & $14.6 \pm 2.1$ & $11.1 \pm 0.1$ & $16.2 \pm 3.0$ \\
\hline 69 & $24.3 \pm 1.3$ & $18.0 \pm 0.8$ & $23.4 \pm 2.1$ & $16.2 \pm 2.0$ & $13.2 \pm 0.3$ & $17.0 \pm 1.0$ & $17.8 \pm 0.5$ & $19.1 \pm 1.7$ \\
\hline 74 & $23.5 \pm 1.3$ & $15.0 \pm 0.5$ & $18.1 \pm 0.5$ & $16.8 \pm 0.6$ & $12.2 \pm 0.3$ & $10.8 \pm 0.6$ & $16.9 \pm 0.4$ & $15.9 \pm 1.1$ \\
\hline 81 & $25.5 \pm 1.4$ & $15.9 \pm 0.5$ & $19.1 \pm 1.1$ & $17.2 \pm 0.6$ & $13.4 \pm 0.4$ & $11.7 \pm 0.5$ & $17.8 \pm 0.4$ & $16.4 \pm 1.2$ \\
\hline
\end{tabular}

Table 4 In-house allometric equation coefficients and coefficient of determination for commonest trees (AG: aboveground biomass, BG: belowground biomass)

\begin{tabular}{llllll}
\hline Tree species & & $a$ & $b$ & $R^{2}$ & dbh range $(\mathrm{cm})$ \\
\hline Trembling aspen & AG & 0.1470 & 2.3280 & 0.954 & $10.2-36.6$ \\
& BG & 0.0271 & 2.3280 & 0.946 & \\
White birch & AG & 0.2151 & 2.2028 & 0.946 & $10.1-29.9$ \\
& BG & 0.0271 & 2.3280 & 0.946 & \\
White spruce & AG & 0.0534 & 2.5844 & 0.960 & $10.0-32.4$ \\
& BG & 0.0375 & 2.3165 & 0.941 & \\
Black spruce & AG & 0.1628 & 2.2634 & 0.961 & $5.9-41.2$ \\
& BG & 0.0930 & 2.0618 & 0.986 & \\
Balsam fir & AG & 0.0329 & 2.7567 & 0.945 & $10.1-27.7$ \\
& BG & 0.0375 & 2.3165 & 0.941 & \\
\hline
\end{tabular}

\section{Results}

\section{Carbon stocks}

\section{Aggregate stocks}

Total carbon stocks ( \pm SE) in the recently harvested stand were $134 \pm 13 \mathrm{Mg} \mathrm{C} \mathrm{ha}^{-1}$, with 27,35 and $38 \%$ in vegetation, detritus and mineral soil, respectively (Table 5, Fig. 1a, b). Carbon stocks in the preharvest mature stand were reduced by $90 \mathrm{Mg} \mathrm{C} \mathrm{ha}^{-1}$ or $40 \%$ by harvesting. In the juvenile stand of age 20, total stocks were $119 \pm 13 \mathrm{Mg} \mathrm{C} \mathrm{ha}^{-1}$, with 26,34 and $40 \%$ in vegetation, detritus and mineral soil. During juvenile stand development the regrowth of the trees and saplings compensated for carbon loss due the decomposition of woody debris and stumps, and total carbon stocks increased by $2 \%$ p.a. to $130 \mathrm{Mg} \mathrm{C}^{-1}$ by age 25 , with vegetation comprising $34 \%$. Mature stands had an average of $208 \mathrm{Mg} \mathrm{C}^{-1}$ with 59,16 and $25 \%$ in vegetation, detritus and mineral soil. Between age 74 and 81 , total stocks increased by 13.3 $\mathrm{Mg} \mathrm{C} \mathrm{ha}{ }^{-1}$ or $1 \%$ p.a. Combined stocks in the detritus and mineral soil layers were 89,94 and $82 \mathrm{Mg} \mathrm{C}^{-1}$ at ages 20,69 and 74, equivalent to 74,42 and $43 \%$ of carbon in the stand. At all ages, these two components made up a large fraction of total stocks, to which the forest canopy added differing amounts according to stand age.

\section{Vegetation components}

Live and dead trees and saplings comprised 7, 43 and $126 \mathrm{Mg} \mathrm{C} \mathrm{ha}^{-1}$, equivalent to $5.3,42$ and $61 \%$ of carbon stocks at 2, 25 and 81 year, respectively (Table 5, Fig. 1a, b). Of these, stocks in live trees and saplings contained 1.6, 41 and $108 \mathrm{Mg} \mathrm{C} \mathrm{ha}^{-1}$, or $1.2,33$ and $52 \%$ of carbon stocks. The clear-cut harvest reduced stocks in live trees and saplings by $98 \%$, from 117 to $1.6 \mathrm{Mg} \mathrm{C} \mathrm{ha}^{-1}$ (Fig. 1a). In the juvenile stand, stocks in live trees and saplings 
Table 5 Mean $( \pm$ SE) carbon stocks in stands

\begin{tabular}{|c|c|c|c|c|c|c|}
\hline \multirow[t]{3}{*}{ Stand component } & \multicolumn{6}{|c|}{ Mass $\left(\mathrm{Mg} \mathrm{C} \mathrm{ha} a^{-1} \mathrm{a}^{-1}\right)$} \\
\hline & \multicolumn{6}{|c|}{ Stand age (years) } \\
\hline & 2 & 20 & 25 & 69 & 74 & 81 \\
\hline \multicolumn{7}{|l|}{ Vegetation } \\
\hline Live trees-AG & $0.75 \pm 0.5$ & $4.2 \pm 0.92$ & $16.1 \pm 3.0$ & $87.0 \pm 11.2$ & $76.5 \pm 12.6$ & $81.8 \pm 12.4$ \\
\hline Live trees-BG & $0.19 \pm 0.12$ & $1.4 \pm 0.28$ & $5.3 \pm 1.0$ & $24.5 \pm 5.2$ & $16.8 \pm 2.2$ & $17.8 \pm 2.1$ \\
\hline Dead trees-AG & $3.9 \pm 1.5$ & $0.8 \pm 0.6$ & $1.15 \pm 0.71$ & $9.2 \pm 2.9$ & $5.7 \pm 1.5$ & $11.2 \pm 2.4$ \\
\hline Dead trees-BG & $0.85 \pm 0.35$ & $0.15 \pm 0.11$ & $0.21 \pm 0.14$ & $1.9 \pm 0.6$ & $1.2 \pm 0.32$ & $2.5 \pm 0.53$ \\
\hline Live saplings-AG & $0.55 \pm 0.32$ & $14.3 \pm 2.7$ & $15.7 \pm 2.9$ & $4.6 \pm 0.85$ & $6.1 \pm 1.1$ & $6.5 \pm 1.8$ \\
\hline Live saplings-BG & $0.13 \pm 0.08$ & $3.6 \pm 0.67$ & $3.9 \pm 0.74$ & $1.2 \pm 0.21$ & $1.5 \pm 0.28$ & $1.6 \pm 0.47$ \\
\hline Dead saplings-AG & $0.55 \pm 0.5$ & $0.45 \pm 0.25$ & $0.3 \pm 0.18$ & $1.1 \pm 0.21$ & $1.9 \pm 0.77$ & $4.0 \pm 0.77$ \\
\hline Dead saplings-BG & $0.14 \pm 0.13$ & $0.1 \pm 0.06$ & $0.08 \pm 0.05$ & $0.25 \pm 0.07$ & $0.4 \pm 0.18$ & $1.0 \pm 0.2$ \\
\hline Shrubs and ground vegetation & $3.3 \pm 0.42$ & $1.8 \pm 0.64$ & $1.3 \pm 0.42$ & $0.35 \pm 0.07$ & $0.73 \pm 1.1$ & $0.83 \pm 0.4$ \\
\hline Stumps-AG & $3.5 \pm 0.46$ & $0.42 \pm 0.07$ & $0.08 \pm 0.02$ & 0 & 0 & 0 \\
\hline Stumps-BG & $22.6 \pm 2.5$ & $3.2 \pm 0.53$ & $0.61 \pm 0.11$ & 0 & 0 & 0 \\
\hline Total vegetation & $36.5 \pm 3.1$ & $30.4 \pm 3.1$ & $44.7 \pm 4.5$ & $130.1 \pm 12.7$ & $110.8 \pm 13.0$ & $127.3 \pm 13.0$ \\
\hline \multicolumn{7}{|l|}{ Detritus } \\
\hline Woody debris-coarse & $7.3 \pm 1.4$ & $0.07 \pm 0.02$ & $0.03 \pm 0.01$ & $4.4 \pm 0.18$ & $2.8 \pm 1.1$ & $2.3 \pm 0.43$ \\
\hline Woody debris-small & $6.5 \pm 1.9$ & $3.6 \pm 0.78$ & $0.75 \pm 0.12$ & $4.7 \pm 0.14$ & $4.2 \pm 0.43$ & $2.2 \pm 0.77$ \\
\hline Woody debris-fine & $1.1 \pm 0.28$ & $0.3 \pm 0.07$ & $0.1 \pm 0.02$ & $2.4 \pm 0.04$ & $0.95 \pm 0.13$ & $0.3 \pm 0.03$ \\
\hline Forest floor organic layer & $30.9 \pm 5.4$ & $36.4 \pm 3.8$ & $36.4 \pm 3.8$ & $30.9 \pm 5.4$ & $22.1 \pm 3.4$ & $22.1 \pm 3.4$ \\
\hline Total detritus & $45.8 \pm 5.9$ & $40.4 \pm 3.9$ & $37.3 \pm 0.25$ & $42.4 \pm 5.4$ & $30.1 \pm 3.6$ & $26.9 \pm 3.5$ \\
\hline Mineral soil to $30 \mathrm{~cm}$ & $32.7 \pm 6.9$ & $37.7 \pm 11.1$ & $37.7 \pm 11.1$ & $32.7 \pm 6.9$ & $33.5 \pm 5.6$ & $33.5 \pm 5.6$ \\
\hline Mineral soil to $60 \mathrm{~cm}$ & $51.2 \pm 11.2$ & $48.2 \pm 11.7$ & $48.2 \pm 11.7$ & $51.2 \pm 11.2$ & $52.4 \pm 6.5$ & $52.4 \pm 6.5$ \\
\hline Overall total & $133.5 \pm 13.1$ & $119.0 \pm 12.6$ & $130.2 \pm 13.1$ & $223.8 \pm 17.9$ & $193.3 \pm 15.0$ & $206.7 \pm 15.0$ \\
\hline
\end{tabular}

$A G$ aboveground, $B G$ belowground

increased by $71 \%$ from 24 to $41 \mathrm{Mg} \mathrm{C}^{-1}$, equivalent to $3.5 \mathrm{Mg} \mathrm{C} \mathrm{ha}^{-1}$ p.a. (15\% p.a.) between age 20 and 25 , whereas in the mature stand, stocks in live trees and saplings increased from 101 to $108 \mathrm{Mg} \mathrm{C} \mathrm{ha}^{-1}$, or about $1 \%$ p.a. between age 74 and 81 .

Carbon stocks in shrubs and herbaceous vegetation contained 67,3 and $0.8 \%$ of the total stocks in living biomass in the 2-, 25- and 81-year-old stands. Removal of the tree canopy during harvest resulted in adding biomass to this stand component, and at age 2, stocks in this component totalled $3.3 \mathrm{Mg} \mathrm{C} \mathrm{ha}^{-1}$, or $2.5 \%$ of stocks, compared to $0.2 \%$ before harvest. In the juvenile stand, stocks in this component were 1.8 and $1.3 \mathrm{Mg} \mathrm{C} \mathrm{ha}^{-1}$ at ages 20 and 25 , or 1.5 and $1 \%$ of total carbon. Shrubs and ground vegetation contained $0.8 \mathrm{Mg} \mathrm{Cha}^{-1}$, or $0.4 \%$ of total stocks in the mature stand at age 74 and 81 . As expected, this stand component only contributed a significant fraction of carbon stocks during the early stages of stand development.
Stumps contributed appreciably to carbon stocks only in the early stages of stand development after harvest; at age 2 stumps contained $26.1 \mathrm{Mg} \mathrm{C}^{-1}$ or $20 \%$ of total carbon (Table 5). Stumps were still present in the juvenile stand, with 3 and $0.5 \%$ of total stocks at ages 20 and 25. At age 69 and later, decomposition incorporated the stump biomass into the forest floor organic layer and mineral soil layer.

\section{Detritus and soil components}

Woody debris carbon was greatest after harvesting, containing $14.9 \mathrm{Mg} \mathrm{C}^{-1}$ or $11 \%$ of stocks. At age 2, coarse and small debris accounted for $93 \%$ of debris mass. In the juvenile stand, woody debris contained 4.0 and $0.9 \mathrm{Mg} \mathrm{C} \mathrm{ha}{ }^{-1}$ at age 20 and 25 , or 6.4 and $1.2 \%$ of stocks. Woody debris carbon in mature stands was greater than in juvenile stands with average totals of $8 \mathrm{Mg} \mathrm{Cha}^{-1}$, or $4 \%$ of stocks. In the mature stands, coarse and small debris comprised an $87 \%$ of total woody debris mass. For all stand ages, fine woody debris ranged between 6.1 and $21 \%$ of 

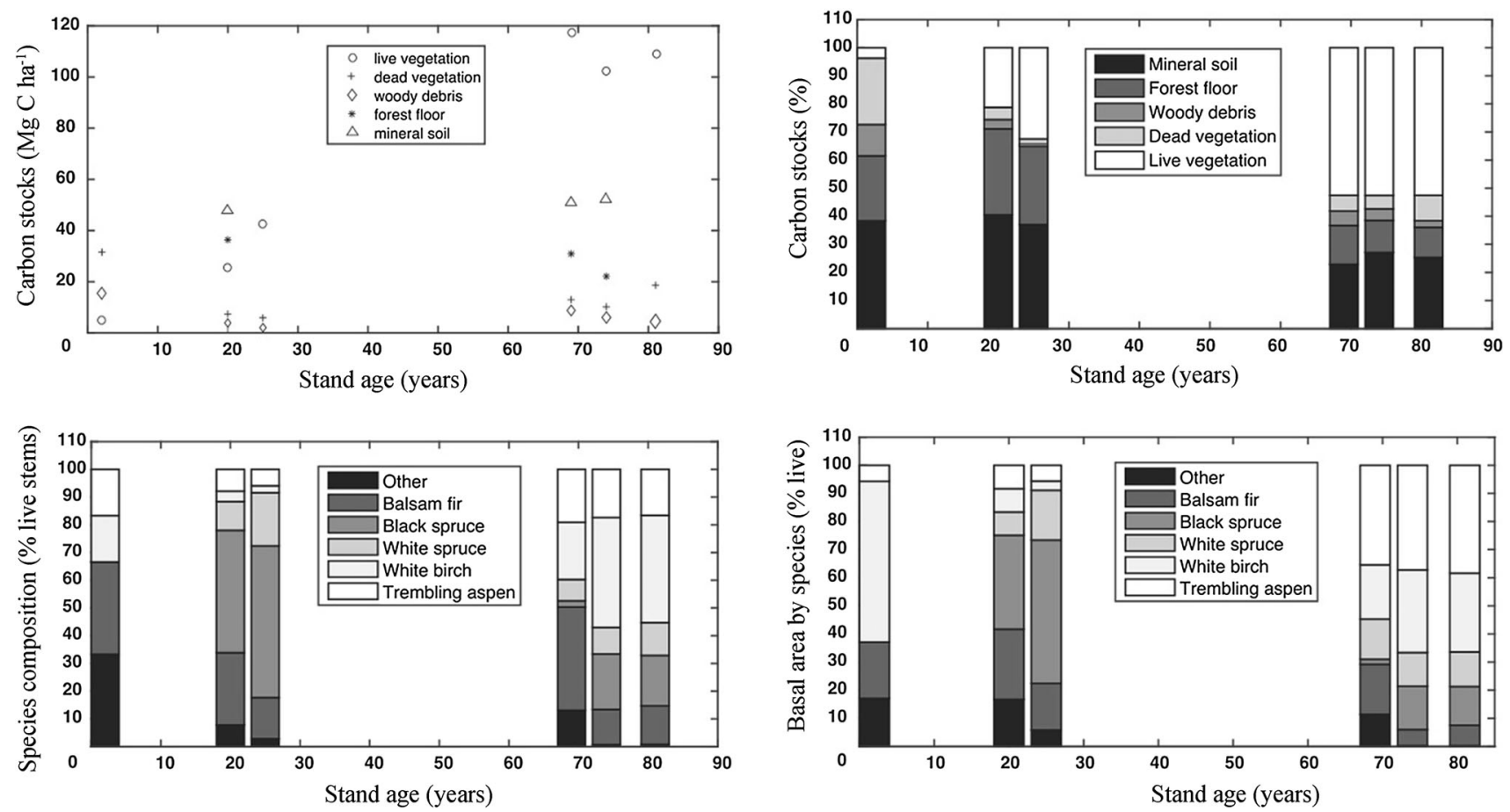

Fig. 1 Mixedwood stand carbon stocks versus age by substrate, and proportion by substrate: mixedwood stand species composition versus age, by stem count and by basal area

total woody debris carbon stocks. Woody debris at the McKeown lake site increased from 11.5 $\mathrm{Mg} \mathrm{C}^{-1}$ at age 69 to $14.9 \mathrm{Mg} \mathrm{Cha}^{-1}$ at age 2 due to the addition of downed branches and debris resulting from harvesting, although the difference was not statistically significant ( $t$ test, $p=0.05)$.

The forest floor organic layer contained 36.4, 30.9 and $22.1 \mathrm{Mg} \mathrm{C} \mathrm{ha}{ }^{-1}$ at ages 20, 69 and 74, or 31, 14 and $11 \%$ of stocks; mean layer depths $( \pm \mathrm{SD})$ were $10.4 \pm 3.3$, $7.5 \pm 3.0$ and $9.3 \pm 6.0 \mathrm{~cm}$. The mineral soil layer to a depth of $60 \mathrm{~cm}$ averaged $51 \mathrm{Mg} \mathrm{C} \mathrm{ha}^{-1}$, and comprised 41,23 and $27 \%$ of stocks at age 20,69 and 74 years. Mineral soil carbon in the $0-30 \mathrm{~cm}$ layer averaged $35 \mathrm{Mg} \mathrm{C} \mathrm{ha}{ }^{-1}$, between 15 and $32 \%$ of carbon stocks in the stand. Mean combined stocks $( \pm \mathrm{SE})$ in the forest floor organic and mineral soil layers were $85 \pm 12,82 \pm 12$ and $75 \pm 7 \mathrm{Mg} \mathrm{C} \mathrm{ha}^{-1}$ at age 20,69 and 74 year, equivalent to 71,37 and $38 \%$ of total stocks.

\section{Aboveground net primary productivity}

In the harvested stand mean annual aboveground NPP (AGNPP) was $2.1 \mathrm{Mg} \mathrm{C}^{-1}$, compared to 3.7 and 2.6 in the juvenile and mature stand (Table 6). Thus, the juvenile stand was most productive, while the harvested and mature stands were adding to aboveground carbon at 59 and $73 \%$ of the rate in the juvenile stand. Tree and sapling growth comprised 7, 73 and $31 \%$ of annual AGNPP in the harvested, juvenile and mature stands. Annual litterfall in the harvested stand averaged $0.3 \mathrm{Mg} \mathrm{C} \mathrm{ha}^{-1}$, compared to 1.1 in the juvenile stand and 1.8 in mature stands contributing 15, 30 and $68 \%$, respectively. The largest contributors to annual AGNPP in the harvested, juvenile and mature stands were the understorey, tree growth and litterfall, respectively. As expected, litterfall in mature canopies was greater than in the harvested and juvenile stands (Table 6).

\section{Forest stand characteristics}

Clear-cut harvest reduced the stem density and basal area (BA) by over $90 \%$, and dead trees accounted for $84 \%$ of postharvest BA (Table 2, Fig. 1c, d). Live trees constituted only $19 \%$ of the $100 \mathrm{ha}^{-1}$ remaining in the harvested stand. In the replanted juvenile stand, the maturing saplings caused stem density and BA to more than triple between ages 20 and 25 , from 250 to $910 \mathrm{ha}^{-1}$, and 2.7 to $9.2 \mathrm{~m}^{2} \mathrm{ha}^{-1}$. Mean spruce tree diameters were similar at year 20 and 25 as more saplings reached the tree dbh threshold (Table 3). In mature stands, the average stem density was $1167\left(\mathrm{ha}^{-1}\right)$, with $92 \%$ live trees. Trembling aspen and white birch made up $51 \%$ of live stems, and white and black spruce and balsam fir accounted for a further $44 \%$ of stems. Basal area in the mature stands averaged $34 \mathrm{~m}^{2} \mathrm{ha}^{-1}$, and total BA only increased by $10 \%$ between stand age 74 and 81 , while mean live tree diameter 
Table 6 Mean $( \pm$ SE) annual aboveground net primary production

\begin{tabular}{|c|c|c|c|}
\hline Stand component & 2 to 3 & $\begin{array}{l}\text { Mass }\left(\mathrm{MgC} \mathrm{ha} \mathrm{Ca}^{-1} \mathrm{a}^{-1}\right) \\
\text { Stand age (year) } \\
20 \text { to } 25\end{array}$ & 74 to 81 \\
\hline Trees & $0.08 \pm 0.14$ & $2.4 \pm 0.6$ & $0.76 \pm 2.5$ \\
\hline Saplings & $0.06 \pm 0.09$ & $0.3 \pm 0.8$ & $0.06 \pm 0.9$ \\
\hline Understorey & $1.6 \pm 0.2$ & $-0.1 \pm 0.15$ & $0.01 \pm 0.17$ \\
\hline Litterfall & $0.33 \pm 0.03$ & $1.1 \pm 0.07$ & $1.8 \pm 0.1$ \\
\hline Total & $2.07 \pm 0.2$ & $3.7 \pm 0.3$ & $2.63 \pm 2.5$ \\
\hline
\end{tabular}

increased by $5 \%$ between year 74 and 81 ; trembling aspen showed the greatest increase, of $14 \%$, whereas spruce dbh only increased by $3 \%$ (Table 3 ).

\section{Discussion}

\section{Boreal forest carbon stocks}

Measured carbon stocks in boreal forest stands at various ages were generally higher in mixedwood than in coniferous stands, and mature trembling aspen stands also held higher stocks than coniferous stands (Fig. 2a). In addition, for a given BA, mixed wood stands generally had higher
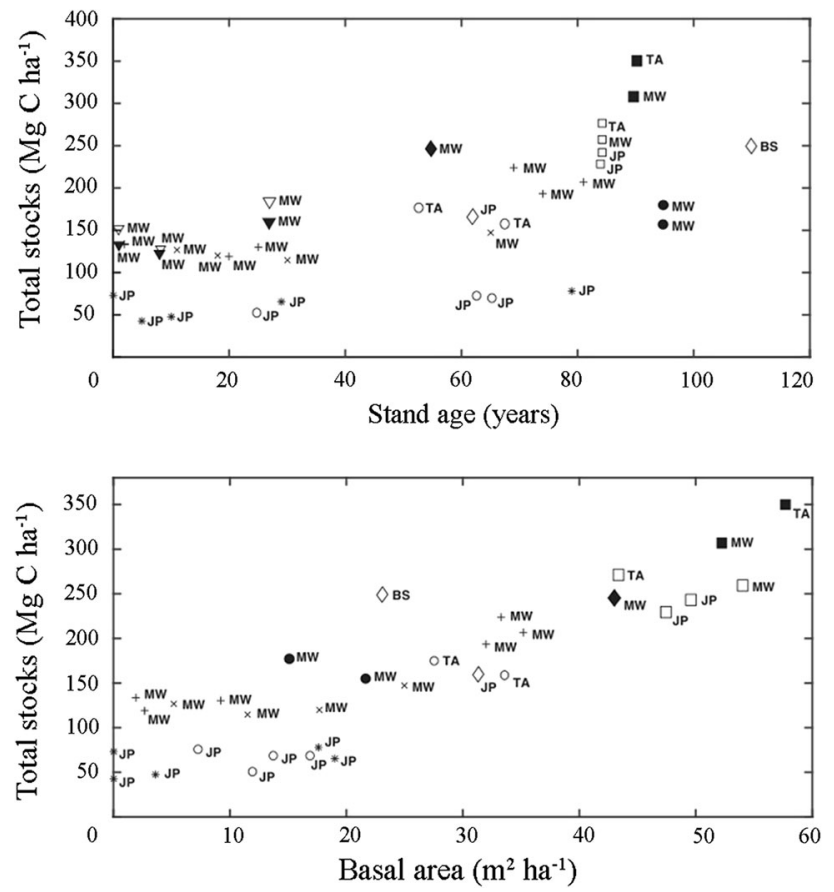

Fig. 2 Total carbon stocks in various boreal forest stand types, by age and by basal area (MW mixedwood, TA trembling aspen, JP jack pine, BS black spruce: plus sign Payne, times sign Martin, asterisk Howard, open circle Gower, closed circle Hazlett, open square Laganiere Ontario, closed square Laganiere Quebec, open diamond Morrison (1993), closed diamond Morrison (2001), open inverted triangle Seedre et al. (2014) cut, closed inverted triangle Seedre et al. (2014) fire) stocks than coniferous stands (Fig. 2b). The mature mixedwood stands studied by Martin et al. (2005), Morrison et al. (2001), Hazlett et al. (2005), Laganière et al. (2015) and those quantified in the present study contained carbon stocks ( $\pm \mathrm{SD}$ ) of $213 \pm 52 \mathrm{Mg} \mathrm{C}^{-1}$, and had an average stand age $( \pm$ SD) of $78 \pm 14$ year. Mature trembling aspen stands studied by Gower et al. (1997) and Laganiere et al. (2015) contained mean carbon stocks ( $\pm \mathrm{SD}$ ) of $239 \pm 89 \mathrm{Mg} \mathrm{C}^{-1}$. Estimated overall carbon stocks in various managed Canadian boreal ecosystems ranged from 140 to $240 \mathrm{Mg} \mathrm{C} \mathrm{ha}^{-1}$, with mean carbon density of 193 (Kurz et al. 2013). Thus, mature mixedwood and trembling aspen stands are typically at or above the average density for Canadian boreal ecosystems.

\section{Vegetation carbon}

Carbon stocks in vegetation for various boreal forest ecosystems typically are higher in this component of mixedwood and trembling aspen stands, as compared to jack pine and black spruce, for a wide range of ages and BA (Fig. 3a, b). In mature mixedwood stands over 60 years of age (mean age \pm SD: $77 \pm 9$ ), the average carbon stocks ( $\pm \mathrm{SD})$ in vegetation were $114 \pm 51 \mathrm{Mg} \mathrm{C} \mathrm{ha}^{-1}$, and on average this comprised $53 \%$ of carbon stocks present. Mature jack pine stand vegetation held stocks of $87 \pm 67 \mathrm{Mg} \mathrm{C} \mathrm{ha}^{-1}$, representing $59 \%$ of total. As might be expected, measurements show a tighter correlation with BA as opposed to age, with roughly $40 \mathrm{Mg} \mathrm{C} \mathrm{ha}^{-1}$ of vegetation carbon added for every $10 \mathrm{~m}^{2} \mathrm{ha}^{-1}$ of BA (Fig. 3b).

Published basal area measurements in various boreal stand types at different ages show that mixedwood and trembling aspen stands typically have higher BA values than jack pine and black spruce stands of similar age (Fig. 3c). Mean basal area ( \pm SD) for mature mixedwood stands was $36 \pm 9 \mathrm{~m}^{2} \mathrm{ha}^{-1}$ in studies by Hazlett et al. (2005), Laganiere et al. (2015), Martin et al. (2005), Morrison et al. (2001), and the present investigation, whereas in mature coniferous stands studied by Gower et al. (1997), Howard et al. (2004), Laganiere et al. (2015) 

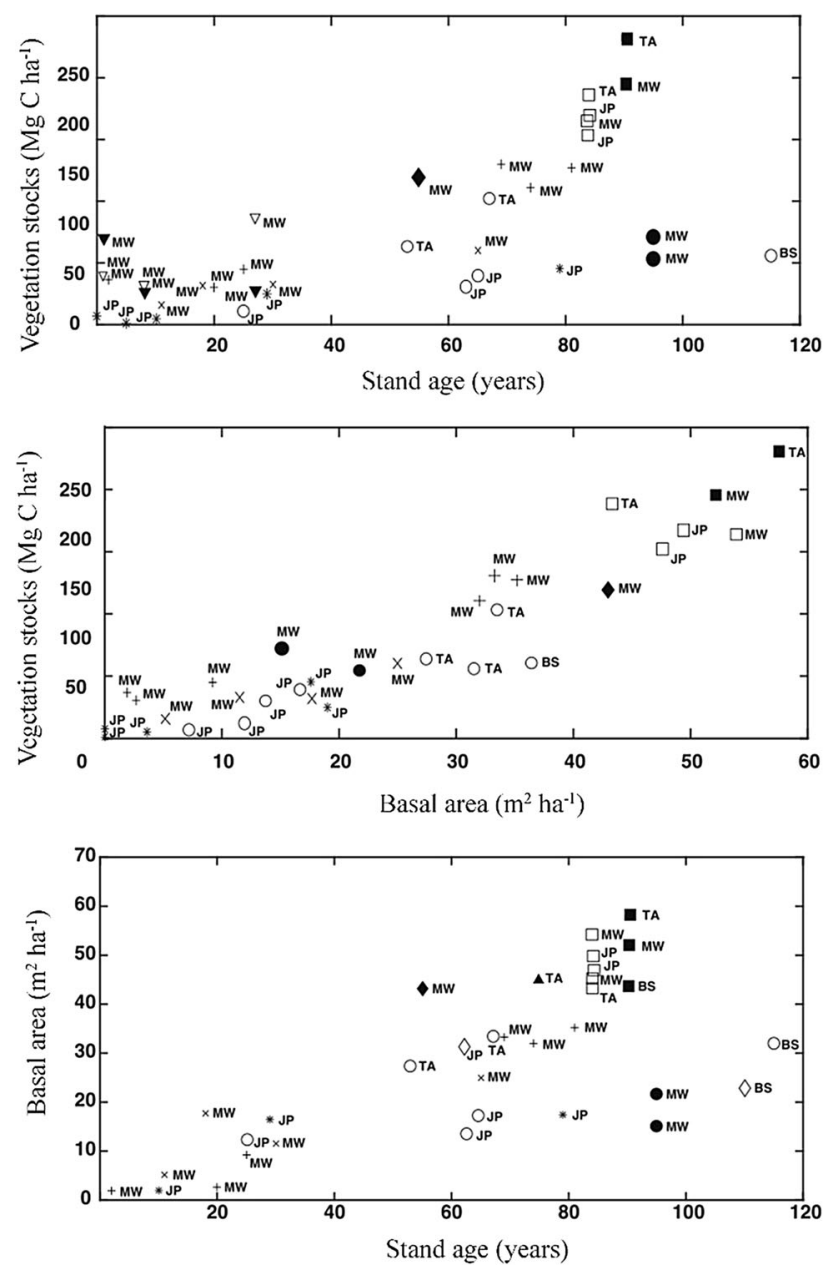

Fig. 3 Vegetation carbon stocks in various boreal forest stand types, by age and by basal area; and basal area by age [MW mixedwood, TA trembling aspen, JP jack pine, BS black spruce: plus sign Payne, times sign Martin, asterisk Howard, open circle Gower, closed circle Hazlett, open square Laganiere Ontario, closed square Laganiere Quebec, open diamond Morrison (1993), closed diamond Morrison (2001), open inverted triangle Seedre et al. (2014) cut, closed inverted triangle Seedre et al. (2014) fire, closed triangle Strukelj et al. (2015)]

and Morrison et al. (1993) mean BA was $31 \pm 14 \mathrm{~m}^{2} \mathrm{ha}^{-1}$.

\section{Detritus and mineral soil carbon}

Forest floor carbon stocks averaged $32 \pm 13 \mathrm{Mg} \mathrm{C}^{-1}$ $( \pm \mathrm{SD}$ ) in mixedwood stands as compared to $16 \pm 6$ in jack pine stands (Fig. 4a, b). In addition, these forest floor organic layer stocks were stable across the observed range of stand age and BA. This characteristic can simplify estimation of carbon stocks held in boreal stands of different ages when planning forest management for optimum carbon sequestration. Carbon stocks in detritus (woody debris plus the forest floor organic layer, Fig. 4c) were generally higher in mixedwood stands
(42 $\left.\pm 13 \mathrm{Mg} \mathrm{C} h a^{-1} ; \pm \mathrm{SD}\right)$, as compared to jack pine stands $\left(19 \pm 9 \mathrm{Mg} \mathrm{Cha}^{-1}\right)$, and in mixedwood stands tended to decrease slightly with age. The overall mean $( \pm \mathrm{SD})$ proportion of stocks found in detritus was $29 \pm 12 \%$, compared to $20 \pm 9 \%$ in the forest floor organic layer alone.

Litter degradation rate is found to vary with tree species, with litter from conifers being slower to degrade than that from deciduous species (Paré et al. 2006). Thus the forest floor layer at the juvenile site restocked with conifers would be expected to degrade more slowly than that at the mature stands comprising of similar proportions of softwood and hardwood trees. Woody debris input is found to increase at harvesting, as in the present study (Brais et al. 2004; Moroni 2006). Brais et al. found decomposition rates of woody debris of about $30 \%$ per year in both a harvested and a mature boreal mixedwood stand in Quebec, whereas in other studies decomposition took up to 30 years, depending on climatic conditions and species (Carlton and Pickford 1982; Prescott et al. 1989; Morrison 1991; Lee et al. 2002). In a survey of coarse and fine woody debris across the United States, Woodall and Liknes (2008) found that production and decay rates are correlated positively with availability of moisture, and negatively with increases in maximum temperature.

Measurements of carbon stocks in mineral soil in boreal stands averaged $62 \pm 15 \mathrm{Mg} \mathrm{C} h a^{-1}( \pm \mathrm{SD})$ and contained $32 \pm 8 \%$ of total carbon stocks (Fig. 4d). As would be expected due to slow accumulation and removal processes, mineral soil stocks did not show obvious age dependence. Because of the magnitude of these mineral soil carbon stocks, it has been suggested that carbon sequestration in boreal forest soils may be a useful strategy to mitigate climate change (Lal 2005). However, improved forest management strategies leading to enhanced carbon sequestration in soil require a better understanding of the dynamics of belowground allocation, heterotrophic respiration and carbon stabilization in the soil (Noormets et al. 2015).

\section{Aboveground NPP}

Annual aboveground NPP measured in various boreal stand types across a range of age and BA was generally higher in mixedwood and trembling aspen stands than in jack pine and black spruce stands (Fig. 5a, b). These measurements generally show lower values of AGNPP when the canopy is young ( $<10$ years) or old ( $>90$ years), with higher values in intermediate years, as exemplified in the present study where carbon stocks in live trees and saplings increased $15 \%$ p.a. in the juvenile stand, compared to $1 \%$ p.a. in the mature stand (Fig. 1a, Table 5). And for a given BA, mixedwood and aspen canopies typically had higher 

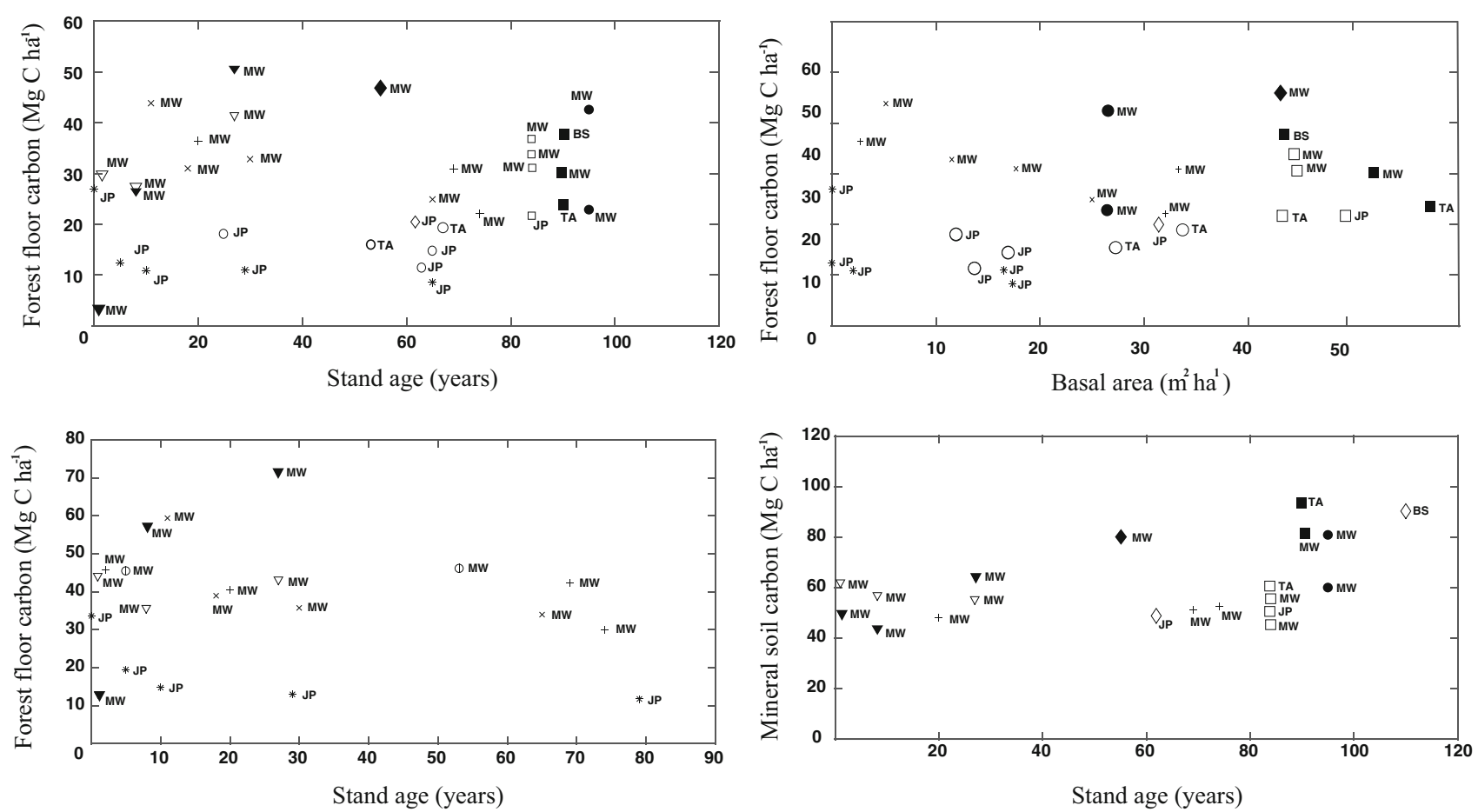

Fig. 4 Forest floor organic layer in various boreal forest stand types by age and by basal area, and detritus and mineral soil carbon stocks by age (MW mixedwood, TA trembling aspen, JP jack pine, BS black spruce: plus sign Payne, times sign Martin, asterisk Howard, open circle Gower, closed circle Hazlett, open square Laganiere Ontario,

AGNPP than coniferous canopies. In addition, with increasing BA, AGNPP in mixedwood and aspen canopies were reduced, but in coniferous canopies AGNPP tended to be more constant across the observed BA range. Boreal forest stand management strategies may be adapted to improve carbon sequestration by taking into account these trends.

The age-related decline in annual AGNPP in the present study is consistent with other studies that have shown that while older forests have the higher $\mathrm{C}$ stocks, younger forests have higher $\mathrm{C}$ absorption capacities (Bond-Lamberty et al. 2004; He et al. 2012). Because annual NPP is the sum of above- and belowground values, the estimates given (Table 6) are lower than the total carbon sequestration in the stand. However, published measurements show that aboveground NPP is typically about two-thirds of total annual NPP (e.g., Bond-Lamberty et al. 2004; Li et al. 2002). For example, in post-fire regenerating black spruce forest, which was mixedwood in composition up to age 50, the aboveground NPP exceeded $78 \%$ of total NPP for stands aged less than 37 years, and averaged $60 \%$ for older stands (Bond-Lamberty et al. 2004). Other field measurements showed that belowground NPP is less than half of total NPP in jack pine, black spruce and trembling aspen stands ( $\mathrm{Li}$ et al. 2002). So aboveground annual NPP

closed square Laganiere Quebec, circled vertical line Lee, open diamond Morrison (1993), closed diamond Morrison (2001), open inverted triangle Seedre et al. (2014) cut, closed inverted triangle Seedre et al. (2014) fire)

estimates provide a useful basis for estimating total annual NPP for the stand.

\section{Implications for boreal forest stand management}

Carbon stocks in mature boreal mixedwood and trembling aspen stands (Fig. 2a; mean 213 and $239 \mathrm{Mg} \mathrm{C} \mathrm{ha}^{-1}$ ) were found to be at or above the average value for those found in various managed boreal forest ecosystems (193 Mg C ha ${ }^{-1}$, Kurz et al. 2013). And carbon stocks in vegetation in mixedwood and trembling aspen stands were typically greater than those found in jack pine and black spruce stands (Fig. 3a). Similarly, carbon stocks in the forest floor organic layer and detritus were typically greater in boreal mixedwood stands, compared to those found in jack pine and black spruce stands (Fig. 4a, c). Annual AGNPP was also greater in mixedwood and trembling aspen stands than in jack pine and black spruce at all stages of stand development (Fig. 5a). Overall, measurements from this and other studies demonstrate the potential value of boreal mixedwood and trembling aspen stands in helping achieve climate change mitigation through enhanced carbon sequestration and provide data needed for quantifying climate change mitigation potential with a view to modifying forest management practices (Lemprière et al. 

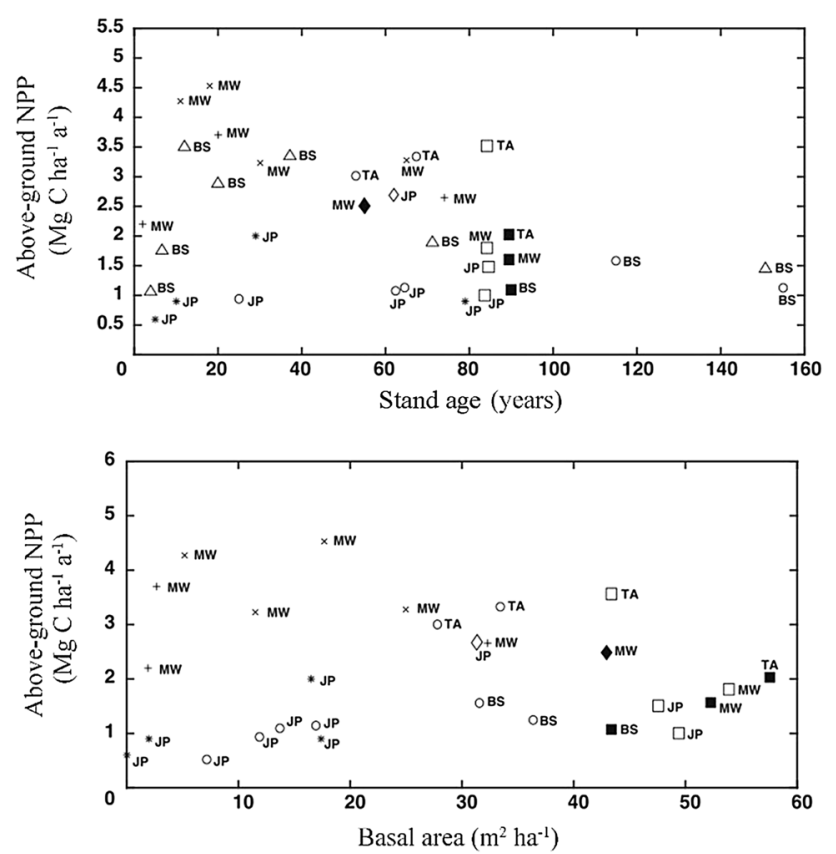

Fig. 5 Aboveground NPP in various boreal forest stand types, by age and by basal area (MW mixedwood, TA trembling aspen, JP jack pine, BS black spruce: plus sign Payne, times sign Martin, asterisk Howard, open circle Gower, open square Laganiere Ontario, closed square Laganiere Quebec, open diamond Morrison (1993), closed diamond Morrison (2001), open triangle Bond-Lamberty)

2013). Investigation of stand thinning as a way to increase carbon sequestration, by taking advantage of the greater NPP in juvenile canopies without large reductions in carbon stocks, may be a worthwhile opportunity for future study.

\section{Conclusion}

Published measurements and those from the present investigation show that total carbon stocks, and those in the vegetation and forest floor organic layer, were typically higher in boreal mixedwood and trembling aspen stands than in coniferous canopies. Of these stocks, the average fraction present in the forest floor organic layer and mineral soil was 20 and $32 \%$, and these components provide relatively stable carbon storage over the stand lifetime, including harvesting. In addition, measurements of annual AGNPP were typically higher in boreal mixedwood and trembling aspen canopies as compared to boreal coniferous canopies. These measurements of AGNPP also reveal higher values in intermediate age stands, as compared those that were recently harvested or mature. The value of boreal mixedwood forest as an above-average ecosystem for carbon sequestration in climate change mitigation is well demonstrated by results from this and other Canadian boreal forest ecosystem studies. Carbon stocks present in boreal mixedwood stands are determined by the particular tree species present and their proportions, as well as the local soil conditions and climate; thus boreal mixedwood carbon stocks over a widespread geographical area can only be estimated from individual stand measurements. However, measurements from the present study, together with other Canadian boreal ecosystem carbon sequestration measurements, can aid decision-making for management practices in Canada's boreal mixedwood forests, e.g., in relation to restocking and timing of harvesting to optimise carbon sequestration and climate-change mitigation.

Acknowledgements Funding for this study was provided by the Canadian Forest Service, with in-kind support from the Ontario Ministry of Natural Resources and Forestry. We thank Jennifer Payne for her expert assistance in creating compound figures.

Open Access This article is distributed under the terms of the Creative Commons Attribution 4.0 International License (http://crea tivecommons.org/licenses/by/4.0/), which permits unrestricted use, distribution, and reproduction in any medium, provided you give appropriate credit to the original author(s) and the source, provide a link to the Creative Commons license, and indicate if changes were made.

\section{References}

Amiro BD, Todd JB, Wooton BM, Logan KA, Flannigan MD, Stocks BJ, Mason JA, Martell DL, Hirsch KG (2001) Direct carbon emissions from Canadian forest fires, 1959-1999. Can J For Res 31(3):512-525

Baldwin KA, MacKenzie WH, Pfalz J, Meades WJ, Meidinger DV, Robataille A, Saucier J-P, Uhlig P (2012) Level 4 map, version 1, Canadian component of the Circumboreal Vegetation Map (CBVM). Canadian regional team of the Circumboreal Vegetation Map Project. Natural Resources Canada, Canadian Forest Service, Great Lakes Forestry Centre, Sault Ste. Marie, ON. Unpublished map

Bélisle J (ed) (1980) Field manual for describing soils. Inst. Pedol., Univ. Guelph, Ont

Bond-Lamberty B, Wang C, Gower S (2004) Net primary production and net ecosystem production of a boreal black spruce wildfire chronosequence. Glob Change Biol 10(4):473-487

Brais S, Harvey BD, Bergeron Y, Messier C, Greene D, Belleau A, Paré D (2004) Testing forest ecosystem management in boreal mixedwoods of northwestern Quebec: initial response of aspen stands to different levels of harvesting. Can J For Res 34(2):431-446

Brandt JP (2009) The extent of the North American boreal zone. Environ Rev 17:101-161

Brassard BW, Han YH, Bergeron Y, Paré D (2011) Coarse root biomass allometric equations for Abies balsamea, Picea mariana, Pinus banksiana, and Populus tremuloides in the boreal forest of Ontario, Canada. Biomass Bioenergy 35(1):4189-4196

Carlton DW, Pickford SG (1982) Fuelbed changes with aging of slash from ponderosa pine thinnings. J For 80(2):91-93

Chapman LJ, Thomas MK (1968) The climate of northern Ontario. Can. Dep. Transport, Meteorological Br. Climatological Studies 6. Toronto 
Chen HYH, Popadiouk R (2002) Dynamics of North American boreal mixedwoods. Environ Rev 10:137-166

Crow TR, Erdmann GG (1983) Weight and volume equations and tables for red maple in the Lake States. U.S. Dep. Agric. For. Serv., North Cent. For. Exp. Stn., St. Paul, MN. Res. Pap. NC242

Dixon RK, Brown S, Houghton RA, Solomon AM, Trexler MC, Wisniewski J (1994) Carbon pools and flux of global forest ecosystems. Science 263(5144):185-189

Environment Canada (2013) Canadian climate normals 1971-2000. http://www.climate.weatheroffice.gc.ca/climate_normals/ results_1971_2000_e.html. Accessed 10 Nov 2016

Gower ST, Vogel JG, Norman JM, Kucharik CJ, Steele SJ, Stow TK (1997) Carbon distribution and aboveground net primary production in aspen, jack pine and black spruce stands in Saskatchewan and Manitoba, Canada. J Geophys Res 102(D24):29029-29041

Hazlett PW, Gordon AM, Sibly PK, Buttle JM (2005) Stand carbon stocks and soil carbon and nitrogen storage for riparian and upland forests of boreal lakes in northeastern Ontario. For Ecol Manage 219(1):56-68

He L, Chen JM, Pan Y, Birdsey R, Kattge J (2012) Relationships between net primary productivity and forest stand age in US forests. Glob Biogeochem Cycles 26(3):GB3009

Howard E, Gower S, Foley J, Kucharik C (2004) Effects of logging on carbon dynamics of a jack pine forest in Saskatchewan, Canada. Glob Change Biol 10(8):1267-1284

IPCC (2014) Climate change 2014: Synthesis report. Contribution of Working Groups I, II and III to Fifth Assessment Report of the Intergovernmental Panel on Climate Change [Core Writing team, R.K. Pachauri and L.A.Mayer, (eds.)]. IPCC, Geneva, Switzerland, p 151

Kurz WA, Shaw CH, Boisvenue C, Stinson G, Metsaranta J, Leckie D, Dyk A, Smyth C, Neilson ET (2013) Carbon in Canada's boreal forest-a synthesis. Environ Rev 21:260-292

Laganière J, Cavard X, Brassard B, Pare D, Bergeron Y, Chen H (2015) The influence of boreal tree species mixtures on ecosystem carbon storage and fluxes. For Ecol Manage 354:119-129

Lal R (2005) Forest soils and carbon sequestration. For Ecol Manage 220:242-258

Landsberg JJ, Gowe ST (1997) Applications of physiological ecology to forest management. Physiological Ecology Series. Academic Press Inc., San Diego

Lee J, Morrison IK, Leblanc JD, Dumas MT, Cameron DA (2002) Carbon sequestration in trees and regrowth vegetation as affected by clearcut and partial cut harvesting in a secondgrowth boreal mixedwood. For Ecol Manage 169(1-2):83-101

Légaré S, Paré D, Bergeron Y (2004) The responses of black spruce growth to an increased proportion of aspen in mixed stands. Can J For Res 34(2):405-416

Lemprière TC, Kurz WA, Hogg EH, Schmoll C, Rampley GJ, Yemshanov D, McKenney DW, Gilsenan R, Beatch A, Blain D, Bhatti JS, Krcmar E (2013) Canadian boreal forests and climate change mitigation. Environ Rev 21:293-321

Li Z, Kurz WA, Apps MA, Beukema SJ (2002) Belowground biomass dynamics in the Carbon Budget Model of the Canadian Forest Sector: recent improvements and implications for the estimation of NPP and NEP. Can J For Res 33(1):126-136

Liu J, Peng C, Apps M, Dang Q, Banfield E, Kurz W (2002) Historic carbon budgets of Ontario's forest ecosystems. For Ecol Manage 169(1-2):103-114

MacDonald GB (1995) The case for boreal mixedwood management: an Ontario perspective. For Chron 71(6):725-734
Martin JL, Gower ST, Plaut J, Holmes B (2005) Carbon pools in a boreal mixedwood logging chronosequence. Glob Change Biol 11(11):1883-1894

McRae DJ, Alexander ME, Stocks BJ (1979) Measurement and description of fuels and fire behavior on prescribed burns: a handbook. Dep. Environ., Can. For. Serv., Sault Ste. Marie, Ont. Inf. Rep. O-X-287

Moroni MT (2006) Disturbance history affects dead wood abundance in Newfoundland boreal forests. Can $\mathbf{J}$ For Res 36(12):3194-3208

Morrison IK (1991) Addition of organic matter and elements to the forest floor of an old growth Acer saccharum forest in the annual litter fall. Can J For Res 21(4):462-468

Morrison IK, Foster NW, Hazlett PW (1993) Carbon reserves, carbon cycling, and harvest effects in three mature forest types in Canada. NZ J For Sci 23(3):403-412

Morrison IK, Lee J Jr, Cameron DA, Leblanc JD, Dumas MT (2001) Carbon distribution and above-ground net production as influenced by harvesting in a second-growth boreal mixedwood forest in eastern Canada, in: Richardson, J.; Bjorheden, R.; P. Hakkila, A.T. Lowe, and C.T. Smith, compilers. Bioenergy from Sustainable Forestry: Principles and Practice. Proceedings of IEA Bioenergy Task 18 Workshop, October 16-20, 2000, Coff's Harbour, New South Wales, Australia. New Zealand Forest Research Institute, Rotorura, New Zealand, Forest Research Bulletin 223. Bottom of Form

National Forest Inventory (2008) Canada's National Forest Inventory: Ground Sampling Guidelines [electronic resource]. https://ca. nfis.org/index_e.html Version 5.0. Accessed 10 Nov 2016

Natural Resources Canada (2012) The state of Canada's forests 2012: annual report [electronic resource]. http://cfs.nrcan.gc.ca/pub warehouse/pdfs/34055.pdf. Accessed 10 Nov 2016

Noormets A, Epron D, Domec JC, McNulty SG, Fox T, Sun G, King JS (2015) Effects of forest management on productivity and caerbon sequestration: A review and hypothesis. For Ecol Manage 335:124-140

Ohmann LF, Grigal DF, Rogers LL (1981) Estimating plant biomass for undergrowth species of northeastern Minnesota forest communities. U.S. Dep. Agric. For. Serv., North Cent. For. Exp. Stn., St. Paul, MN. Gen. Tech. Rep. NC-61

Paré D, Bergeron Y (1995) Above-ground biomass along a 230-year chronosequence in the southern portion of the Canadian boreal forest. J Ecol 83(6):1001-1007

Paré D, Boutin R, Larocque GR, Raulier F (2006) Effect of temperature on soil organic matter decomposition in three forest biomes of eastern Canada. Can J Soil Sci 86:247-256

Perala DA, Alban DH (1994) Allometric biomass estimators for aspen-dominated ecosystems in the Upper Great Lakes. U.S. Dep. Agric. For. Serv., North Cent. For. Exp. Stn., St. Paul, MN. Res. Pap. NC-314

Prescott CE, Corbin JP, Parkinson D (1989) Input, accumulation and residence times of carbon, nitrogen and phosphorus in four Rocky Mountain coniferous forests. Can J For Res 19(3):489-498

Roussopoulous PJ, Loomis RM (1979) Weights and dimensional properties of shrubs and small trees of the Great Lakes conifer forest. U.S. Dep. Agric. For. Serv., North Cent. For. Exp. Stn., St. Paul, MN. Res. Pap. NC-178

Seedre M, Taylor AR, Brassard BW, Chen HY, Jõgiste K (2014) Recovery of ecosystem carbon stocks in young boreal forests: a comparison of harvesting and wildfire disturbance. Ecosystems $17: 851-863$

Smith WB, Brand GJ (1983) Allometric biomass equations for 98 species of herbs, shrubs, and small trees. U.S. Dep. Agric. For. Serv., N. Central For. Exp. Sta., St. Paul, MN. Res. Note NC-299 
Soil Classification Working Group (1998) The Canadian system of soil classification. Agric Agri-Food Can. Publ. 1646 (revised)

Strukelj M, Brais S, Paré D (2015) Nine-year changes in carbon dynamics following different intensities of harvesting in boreal aspen stands. Eur J Forest Res 134(5):737-754

Ter-Mikaelian MT, Korzukhin MD (1997) Biomass equations for sixty-five North American tree species. For Ecol Manage 97(1):1-24

Towill WD (1996) Ontario's boreal mixed forest: distribution, extent, and importance, p. 21 in: Smith, C. R.; Crook, G. W. (compilers). Advancing Boreal Mixedwood Management in Ontario. Proceedings of a Workshop, 17-19 Oct. 1995, Sault Sainte Marie, ON. Can. For. Serv., Sault Sainte Marie, ON
Van Wagner CE (1968) The line intersect method in forest fuel sampling. For Sci 14(1):20-26

Woodall CW, Liknes GC (2008) Relationships between forest fine and coarse woody debris carbon stocks across latitudinal gradients in the United States as an indicator of climate change effects. Ecol Ind 8(5):686-690

\section{Publisher's Note}

Springer Nature remains neutral with regard to jurisdictional claims in published maps and institutional affiliations. 